\title{
Klinik Calıșma
}

\section{Koroner Baypas Cerrahisinde Sevofluran ve Desfluranın Miyokardiyal Koruma Üzerine Etkilerinin Propofol ile Karşılaştırılması}

\author{
Esin ERDEM*, Belkıs TANRIVERDIं**, Dilek CEYHAN**
}

\section{ÖZET}

Amaç: Bu çalışmanın amacı kardiyopulmoner baypas (KPB) cerrahisi uygulanacak hastalarda sevofluran ve desfluranın miyokart üzerindeki koruyucu etkilerini propofolün miyokart üzerindeki koruyucu etkileri ile miyokart hasarlanma belirteçleri kullanarak karşılaştormaktir.

Gereç ve Yöntem: Etomidat $0.3 \mathrm{mgkg}^{-1}$ ile anestezi indüksiyonundan sonra $0.1 \mathrm{mgkg}^{-1}$ pankuronyum verildi. Anestezi idamesi Grup S: sevofluran (n: 20) \% 2-4, Grup D: desfluran (n: 20) \%7-8 veya Grup K: propofol $50 \mu \mathrm{gkg}^{-1} \mathrm{dk}^{-1}$ ile sağlandr. Anestezi indüksiyonu öncesi, aort klempi kaldırıldiktan sonra, postoperatif 2 . ve 24. saatte kan örnekleri alındl. Tüm kan örneklerinden troponin I, kreatinin kinaz (CK) ve kreatinin kinaz MB (CKMB) değerleri ölçüldü. Ayrıca aortaya klemp yerleştirildikten, aort klempi kaldırıldıktan sonra ve protomin uygulaması sonrası alınan kan örneklerinde malonil dialdehit (MDA) değerleri ölçüldü.

Bulgular: Gruplar arasında demografik veriler, greft sayısı ve KPB pompa süresi açısından istatistiksel yönden fark yoktu. Troponin I ve CK düzeyleri aort klempi kaldırldiktan sonra, postoperatif 2. ve 24. saatte tüm gruplarda arttı. Ancak bu artıs gruplar karşılaştırıldiğında istatistiksel yönden anlamlı değildi. Yine MDA düzeyindeki artışlarda istatistiksel yönden anlaml değildi. Tüm gruplardaki CKMB düzeyleri postoperatif 2. ve 24. saatte artt, ancak bu artış sevofuran grubunda desfluran ve propofol grubuna göre daha azdi.

Sonuç: Sevofluran, desfluran ve propofol benzer kardiyak koruyucu etkiye sahiptir.

Anahtar kelimeler: sevofluran, desfluran, miyokardiyal koruma, koroner baypas cerrahisi

Alındığı tarih: 17.06.2014

Kabul tarihi: 10.10 .2014

* Bozüyük Devlett Hastanesi Anesteziyoloji ve Reanimasyon Kliniği

** Osmangazi Üniversitesi Tıp Fakültesi Anesteziyoloji ve Reanimasyon Anabilim Dalı

Yazışma adresi: Yrd. Doç. Dr. Dilek Ceyhan, Eskişehir Osmangazi Üniversitesi Tip Fakültesi Anesteziyoloji ve Reanimasyon Anabilim Dalı, 26100 Eskişehir

e-mail: drdcetinkaya@mynet.com

\section{SUMMARY}

Effects of Sevoflurane and Desflurane on Myocardial Protection in Comparison with Propofol in Coronary Bypass Surgery

Objective: The aim of this study is to compare myocardial protective effects of sevoflurane and desflurane and with myocardial protective effects of propofol via markers of myocardial injury in cardiopulmonary bypass graft surgery (CPB).

Material and Methods: After induction of general anesthesia with etomidate $0.3 \mathrm{mg} / \mathrm{kg}$, a bolus dose of pancuronium $0.1 \mathrm{mg} / \mathrm{kg}$ was administered. For the maintenance of anesthesia, patients received either Group S: sevoflurane (n:20) at 2-4\%, Group D: desflurane (n:20) at 7-8 \% and Group K:propofol (n:20) at $50 \mu \mathrm{gk}^{\mathrm{g}-1} \mathrm{dk^{-1 }}$. Arterial blood samples were obtained as follows: before induction of anesthesia, after aortic unclamping, at postoperative 2nd, and 24th hours. Troponin I, creatine kinase $(C K)$ and creatine kinase-MB (CKMB) values were measured in all obtained samples. In addition, arterial blood samples were obtained after aortic unclamping, and protamine infusuion, and malonil dialdehyde (MDA)levels were measured.

Results: No statistically significant difference was found among the groups with respect to demographic characteristics, number of grafts, duration of CPB pump. Troponin I and CK levels of all groups increased after aortic clamp placement, at postoperative 2nd and 24th hours. However these increases were not statistically significant. Also, there was no significant increase of MDA levels in all groups. Creatinin kinase MB levels of all groups increased at postoperative 2 nd and 24 th hours but this increase in sevoflurane group was lesser than propofol and desflurane groups.

Conclusion: Sevoflurane, desflurane and propofol have similar cardioprotective characteristics.

Key words: sevoflurane, desflurane, myocardial protection, coronary bypass surgery 


\section{GíRiş}

Miyokard kardiyopulmoner baypas (KPB) sirasinda global iskemik hasara maruz kalmaktadır ${ }^{[1]}$. Ayrıca iskemi sona erdikten sonra perfüzyonun başlaması ile oluşan reperfüzyon hasarı da miyokard için ciddi sorunlara yol açmaktadır. Bu ameliyatı geçirecek olgularda seçilecek anestezi yönteminin; intraoperatif ve postoperatif dönemlerde yeterli düzeyde analjezi ve amnezi sağlaması, hemodinamik stabiliteyi korumas1, kas gevşeticilerin birikici etkisinin ekstübasyonu önleyecek düzeyde olmaması, miyokardiyal iskemi ataklarını önlemesi ve hipotermik kardiyopulmoner baypas dönemlerinde miyokardı hasardan koruması gerekmektedir ${ }^{[2]}$.

Son yıllarda yapılan çalışmalar anestezi tekniklerinin, özellikle de inhalasyon anestezik ajanlarının miyokardiyal koruma sağladığını göstermektedir ${ }^{[3]}$. Volatil anesteziklerin klinik konsantrasyonları infark boyutunda azalma ve reperfüzyon sonrasında kontraktil fonksiyonun daha hızlı düzelmesi ile miyokardı iskemi ve reperfüzyon hasarından korumaktadır ${ }^{[4]}$.

Miyokard hasarının biyokimyasal belirteçleri olarak aspartat transaminaz, kreatinin kinaz (CK), kardiyak spesifik kreatinin kinaz MB (CKMB) kullanılmaktadır. Koroner baypas cerrahisi sonrasında kardiyak Troponin T ve Troponin I miyokard hasarını yansitması açısından daha spesifik bulunmuştur ${ }^{[5]}$.

Kardiyopulmoner baypas sırasında oluşan iskemi reperfüzyon hasarının patofizyolojisinde miyokardtan salınan serbest oksijen radikallerinin rol oynadığ 1 gösterilmiştir ${ }^{[6]}$. Serbest radikaller, hücre membranlarında lipit peroksidasyonuna neden olur ve son ürün olarak malon (il) dialdehit (MDA) meydana gelir. $\mathrm{Bu}$ olgularda iskemi sonunda süperoksit radikal üretiminin ve MDA seviyesinin arttığı bildirilmektedir ${ }^{[7]}$.

$\mathrm{Bu}$ çalışmanın amacı açık kalp cerrahisi uygulanacak hastalara sevofluran ve desfluranın miyokard üzerindeki koruyucu etkilerini miyokard hasarlanma belirteçleri kullanarak, propofol verilen hastalar ile karş1laştırmaktır.

\section{GEREÇ ve YÖNTEM}

Bu araştırma Fakülte Etik Kurul onamı (373 sayı ve
2009 tarih) ve hasta onamları alındıktan sonra randomize olarak yapıldı. Elektif KPB uygulanacak ASA II-III, 48-69 yaş arası 60 hasta üzerinde gerçekleştirildi.

Son 6 hafta içerisinde miyokard enfarktüsü geçirmiş olan, ejeksiyon fraksiyonu (EF) \% 40'ın altında olan, valvüler ya da aortik cerrahi uygulanacak hastalar, acil olgular, hemodinamik açıdan stabil olmayan (cerrahi öncesi inotropik ajan ya da intraaortik balon pompası gereksinimi olan hastalar), şiddetli sistemik hastalığı olanlar çalışma dışı bırakıldı.

Tüm hastalara ameliyattan bir saat önce $0.1 \mathrm{mgkg}^{-1}$ morfin intramusküler olarak yapıldı. Hastalar ameliyat masasına alındıktan sonra elektrokardiyogram, pulse oksimetre ve noninvaziv tansiyon manşonu kullanılarak monitorize edildi. Başlangıç değerleri kayıt edildi. Takiben hastalara $0.3 \mathrm{mgkg}^{-1}$ etomidat, 0.1 $\mathrm{mgkg}^{-1}$ pankuronyum verilerek indüksiyon sağlandı. Hastalar kapalı zarf yöntemi kullanılarak 3 gruba ayrıldı. Takiben Grup S (sevofluran grubu)'deki hastalara \% 2-4 sevofluran, Grup D (desfluran grubu)'deki hastalara \% 7-8 desfluran başlanarak tüm ameliyat boyunca devam edildi. Grup K (kontrol grubu)'daki hastaların idamesi ise $50-100 \mu \mathrm{gkg}^{-1} \mathrm{dk}^{-1}\left(5-8 \mathrm{mgkg}^{-1} \mathrm{~h}^{-1}\right)$ propofol ile sağlandı. Her 3 gruptaki hastalara 0.1-0.3 $\mu \mathrm{gkg}^{-1} \mathrm{dk}^{-1}$ remifentanil infüzyonu indüksiyonu takiben başlandı ve tüm ameliyat boyunca devam edildi. Entübasyonu takiben hastalar \% 50 oksijen-\% 50 kuru hava karışımı ile $8-10 \mathrm{mLkg}^{-1}$ tidal volüm ile mekanik ventilatöre bağlandı.

Hastalara sağ ya da sol radiyal artere 20 gauge kanül, sağ internal vene ise 8 french 3 lümenli kateter yerleştirildi. Tüm hastaların kalp atım hızları (KAH) ve ortalama arteriyel basınç değerleri (OAB); indüksiyon öncesi (t1), indüksiyon sonrası (t2), entübasyon sonrası (t3), cilt insizyonu sonrası (t4), sternotomi sonrası (t5), kros klemp kaldırıldıktan sonra (t6), baypas bitişi sonrası 10. (t7) ve 20. dk.'larda (t8), yoğun bakımda 1. (t9), 6. (t10), 12. (t11) ve 24. saatlerde (t12) kaydedildi. Ayrıca hastaların EF değerleri, ameliyat sırasında baypas uygulanılan damar sayıları ve pompa süreleri de not edildi.

Hastalar yüzeyel anestezi belirtileri açısından sürekli olarak gözlendi. Kalp atım hızında ve OAB'ndaki yükselmeler (OAB değerinin baypas dönemi süresince 
$1 \mathrm{dk}$. ya da daha uzun süre $>130 \mathrm{mmHg}$, kalp hızının $1 \mathrm{dk}$. ya da daha uzun süre $>100$ atımdk $^{-1}$ olması), somatik yanitlar (hareketlenme, kaş çatma, göz açma, yutkunma) ve otonomik yanıtlar (terleme, göz yaşarması) yüzeyel anestezi belirtileri olarak kabul edildi. $\mathrm{Bu}$ belirtiler saptandığında sevofluran, desfluran ve propofol dozları arttırıldı (Sevofluran konsantrasyonu \% 0,5, Desfluran konsantrasyonu \% 1, propofol dozu $5 \mu \mathrm{gkg}^{-1} \mathrm{dk}^{-1}$ arttırıld1). Desfluran, sevofluran ve propofol dozları arttırılmasına rağmen, kan basınc1 yüksekliği devam ettiğinde nitrogliserin (0.25-1 $\mu \mathrm{gkg}^{-1} \mathrm{dk}^{-1}$ dozunda verildi.

Hipotansiyon (OAB değerinin baypas dönemi süresince $1 \mathrm{dk}$. ya da daha uzun süre $<40 \mathrm{mmHg}$ olması), eğer hastalar hipovolemik ise intravenöz sıvı artt1rılması ile tedavi edildi. Yanıt alınamayan olgularda opioid veya anestezik dozları düşürüldü. Bunlara rağmen, yanıt alınamayan hastalara inotropik ajan başlandı. Çalışma için kabul edilebilir inotropik destek dozu Dopamin: 3-5 $\mu \mathrm{gkg}^{-1} \mathrm{dk}$ olarak belirlendi.

Hastalara $300 \mathrm{U} \mathrm{kg}^{-1}$ heparin intravenöz yoldan yapıldı ve aktive edilmiş pıhtılaşma zamanı (ACT) 450-600 saniye arasında tutuldu. Aort ve vena cava kanülasyonlarını takiben ekstrakorporeal dolaşıma geçildi. Ekstrakorporeal dolaşım süresince hematokrit \% 25-30, OAB 60-100 mmHg, baypas debisi 2-2,5 $\mathrm{Lm}^{2}$ düzeyinde tutuldu. Membranöz oksijenatör kullanild.

Kros klemp uygulamasını takiben antegrat/retrograt kardiyopleji uygulandı ve topikal hipotermi yapıldı. Tüm hastalar ekstrakorporeal dolaşım süresince orta derecede hipotermide $\left(28-32^{\circ} \mathrm{C}\right)$ tutuldu. Ekstrakorporeal dolaşım süresince Grup D'deki hastalara \% 2-3 volümde desfluran, Grup S'deki hastalara ise \% 1-2 volümde sevofluran, Grup K'deki hastalara da $50 \mu \mathrm{gkg}^{-1} \mathrm{dk}^{-1}$ propofol verildi. Ekstrakorporeal dolaşım sona erince eski dozlara dönüldü.

Tüm olguların kros klemp süreleri ve total baypas süreleri kaydedildi. Kardiyopulmoner baypastan ayrılma sırasında ventriküler fibrilasyon gelişen ve defibrile edilen hastalar çalışmaya dâhil edilmedi.

Cerrahinin sona ermesi ile anestezik ajanlar kesildi ve hastalar yoğun bakıma transfer edildi. Yoğun bakım ünitesinde hastalar mekanik ventilatöre alındı ve he- modinamik kayitlar alınmaya devam edildi.

Troponin I, CK, CKMB için kan örnekleri; anestezi indüksiyonu öncesi, kros klemp kaldırıldıktan hemen sonra, postoperatif 2. saatte, postoperatif 24. saatte çalışıldı. Teknik olarak "Electrochemiluminescence immunoassay analizörü" (Cobas, Roche, USA) kullanıldi.

Malon (il) dialdehit için kan örnekleri; kros klemp yerleştirdikten sonra, kros klemp kaldırıldıktan sonra ve protamin uygulama sonrası olmak üzere UV-1201 Shimadzu spektrofotometre (Shimadzu Corp., Japan) kullanılarak çalışıldı.

Çalışmada elde edilen bulgular değerlendirilirken, istatistiksel analizler için SPSS 11 (İstatistik Paket programı) kullanıldı. Çalışma verileri değerlendirilirken tanımlayıcı istatistiksel metotların (Ortalama, Standart sapma) yanı sıra normal dağılımın incelenmesi için Kolmogorov-Smirnov dağılım testi kullanıldi. Niteliksel verilerin karşılaştırılmasında ise ki-kare testi ve Fisher Exact testi kullanıldı. Niceliksel verilerin karşılaştırılmasında 2'den fazla grup durumunda, normal dağılım gösteren parametrelerin gruplar arası karşılaş̧ırmalarında One way Anova testi ve farklılığa neden olan grubun tespitinde Tukey testi kullanıldı. Niceliksel verilerin karşılaştırılmasında 2'den fazla grup durumunda, normal dağılım göstermeyen parametrelerin gruplar arası karşılaştırmalarında Kruskal Wallis testi ve farklılığa neden olan grubun tespitinde Mann Whitney U testi kullanıldı. Parametrelerin grup içi karşılaştırmalarında ise Bonferroni ve Wilcoxon testi kullanıldı. Sonuçlar \% 95'lik güven aralığında, $\mathrm{p}<0.05$ anlamlılık ve $\mathrm{p}<0.01$ ileri anlamlılık düzeyinde değerlendirildi.

\section{BULGULAR}

Bu çalışma yaşları 48 ile 69 arasında değişmekte olan 15'i (\% 25) kadın; 45’i (\% 75) erkek toplam 60 olgu üzerinde uygulandı. Hastaların demografik verileri, cerrahi değiştirme yapılan damar sayısı ve pompa süreleri açısından gruplar arasında fark bulunamadı (Tablo 1).

Hastalarda KAH açısından fark bulunamadı. Grup S'deki olguların indüksiyon öncesi, indüksiyon sonrası, entübasyon sonrası, cilt insizyonu sonrası OAB 
Tablo 1. Hastaların demografik verileri, cerrahi değiștirme yapılan damar sayısı ve pompa süreleri.

\begin{tabular}{lcccc}
\hline & $\begin{array}{c}\text { Grup S } \\
(\mathbf{n}: 20)\end{array}$ & $\begin{array}{c}\text { Grup D } \\
(\mathbf{n}: 20)\end{array}$ & $\begin{array}{c}\text { Grup K } \\
(\mathbf{n}: 20)\end{array}$ & p \\
\hline Yaş (median \pm SS) & $66.25 \pm 9.04$ & $64.8 \pm 8.55$ & $63.35 \pm 9.24$ & 0.595 \\
Ağırlık (median $\pm S S)$ & $68.2 \pm 7.91$ & $68.25 \pm 8.24$ & $65.85 \pm 7.78$ & 0.558 \\
Cinsiyet (K/E) & $7 / 13$ & $3 / 17$ & $5 / 15$ & 0.197 \\
ASA II/III & $14 / 6$ & $15 / 5$ & $14 / 6$ & 0.954 \\
EF (\%) & $54.5 \pm 8.58$ & $48.8 \pm 9.38$ & $51.2 \pm 11.11$ & 0.152 \\
Pompa süresi (dk.) & $75 \pm 24.92$ & $69.25 \pm 26.62$ & $59 \pm 24.74$ & 0.066 \\
Damar sayıs1 & $2.7 \pm 0.65$ & $3 \pm 0.64$ & $2.8 \pm 0.58$ & 0.319 \\
\hline
\end{tabular}

SS: Standart deviasyon, E: Erkek K: Kadın, ASA: American Society of Anesthesiologists, dk.: dakika

Tablo 2. Troponin I ölçümlerinin gruplara göre dağılımı.

\begin{tabular}{lcccc}
\hline Troponin I (ngmL & $\begin{array}{c}\text { Grup S } \\
(\mathbf{n : 2 0})\end{array}$ & $\begin{array}{c}\text { Grup D } \\
(\mathbf{n : 2 0})\end{array}$ & $\begin{array}{c}\text { Grup K } \\
(\mathbf{n : 2 0})\end{array}$ & $\mathbf{p}$ \\
\hline $\begin{array}{l}\text { Indüksiyon öncesi } \\
\text { (median } \pm \text { SS) }\end{array}$ & $0.15 \pm 0.67$ & $0.60 \pm 2.01$ & $0.05 \pm 0.22$ & 0.329 \\
$\begin{array}{l}\text { Kros klemp sonras1 } \\
\text { (median } \pm \text { SS) }\end{array}$ & $0.15 \pm 0.48 *$ & $0.75 \pm 2.67 * *$ & $0.10 \pm 0.30 * * *$ & 0.357 \\
$\begin{array}{l}\text { Post-op 2. saat } \\
\text { (median } \pm S S)\end{array}$ & $6.55 \pm 2.58 *$ & $6.30 \pm 5.15 * *$ & $5.80 \pm 2.16 * * *$ & 0.795 \\
$\begin{array}{l}\text { Post-op 24. saat } \\
\text { (median } \pm S S)\end{array}$ & $2.70 \pm 1.97$ & $3.70 \pm 3.48$ & $2.50 \pm 2.28$ & 0.318 \\
\hline
\end{tabular}

SS: Standart deviasyon, *,**,***p<0.05 (Grup içinde kros klemp sonrası ve postoperatif 2 . saat karşılaştırması)

Tablo 3. Kreatinin kinaz ölçümlerinin gruplara göre dağılımı.

\begin{tabular}{|c|c|c|c|c|}
\hline $\begin{array}{l}\text { Kreatin Kinaz } \\
\text { (U/L) }\end{array}$ & $\begin{array}{c}\text { Grup S } \\
(\mathrm{n}: 20)\end{array}$ & $\begin{array}{l}\text { Grup D } \\
(\mathbf{n}: 20)\end{array}$ & $\begin{array}{l}\text { Grup K } \\
(\mathbf{n}: 20)\end{array}$ & $\mathbf{p}$ \\
\hline $\begin{array}{l}\text { İndüksiyon öncesi } \\
(\text { median } \pm S S)\end{array}$ & $70.70 \pm 42.95$ & $83.9 \pm 81.4$ & $66.8 \pm 49.3$ & 0.647 \\
\hline $\begin{array}{l}\text { Kros klemp sonras } \\
(\text { median } \pm \text { SS })\end{array}$ & $65.05 \pm 24.84 *$ & $119.6 \pm 18.2^{* * *}$ & $56.3 \pm 31.03^{* * *}$ & 0.187 \\
\hline $\begin{array}{l}\text { Post-op 2. saat } \\
\text { (median } \pm S S)\end{array}$ & $403.2 \pm 190.1^{*}$ & $395.3 \pm 202.5 * *$ & $291.8 \pm 135.9^{* * * *}$ & 0.098 \\
\hline $\begin{array}{l}\text { Post-op 24. saat } \\
\text { (median } \pm \text { SS) }\end{array}$ & $501.2 \pm 248.1^{*}$ & $540.6 \pm 265.6^{* *}$ & $535.5 \pm 255.6^{* * *}$ & 0.870 \\
\hline
\end{tabular}

SS:Standart deviasyon, *,**,***p<0.05 (Grup içi kros klemp sonrast, post-op 2. saat ve 24. saat karşılaştırlmast)

ölçümleri, Grup D ve Grup K'deki olgulara göre anlamlı olarak düşük bulundu $(\mathrm{p}<0.01)$ (Şekil 1). Hastalarda KPB dan ayrılmayı takiben Grup S'de 1, Grup D'de 1 ve Grup K'de 2 hastada hipotansiyon gelişti. Sıvı replasmanı takiben hipotansiyon düzeldi.

Sevofluran grubunda kros klemp sonrası Troponin I değeri, indüksiyon öncesi Troponin I değerine göre değişmezken, Desfluran ve kontrol grubunda artış gösterdi. Her 3 grupta postoperatif 2. saatteki artış kros klemp sonrası değere göre anlamlıydı. Normal
Tablo 4. Kreatinin kinaz MB ölçümlerinin gruplara göre dağılımı.

\begin{tabular}{lcccc}
\hline $\begin{array}{l}\text { Kreatin Kinaz } \\
\text { MB (U/L) }\end{array}$ & $\begin{array}{c}\text { Grup S } \\
(\mathbf{n : 2 0})\end{array}$ & $\begin{array}{c}\text { Grup D } \\
(\mathbf{n : 2 0})\end{array}$ & $\begin{array}{c}\text { Grup K } \\
(\mathbf{n : 2 0})\end{array}$ & p \\
\hline $\begin{array}{l}\text { İndüksiyon öncesi } \\
\text { (median } \pm \text { SS) }\end{array}$ & $46.3 \pm 27.9^{* *}$ & $36.4 \pm 18.6$ & $38.1 \pm 14.5$ & 0.290 \\
$\begin{array}{l}\text { Kros klemp sonras1 } \\
\text { (median } \pm \text { SS) }\end{array}$ & $27.7 \pm 10.4^{* *}$ & $35.1 \pm 15.3$ & $27.2 \pm 11.2$ & 0.093 \\
$\begin{array}{l}\text { Post-op 2. saat } \\
\text { (median } \pm \text { SS) }\end{array}$ & $59.6 \pm 25.4$ & $80.1 \pm 36$ & $84.8 \pm 36.8$ & $0.045^{*}$ \\
$\begin{array}{l}\text { Post-op 24. saat } \\
\text { (median } \pm \text { SS) }\end{array}$ & $43.2 \pm 13.4$ & $79.2 \pm 13.3$ & $75.8 \pm 15.3$ & 0.413 \\
\hline
\end{tabular}

SS: Standart deviasyon, * ${ }^{*}<0.05$ Gruplar arası karşılaştırma, **Grup içi indüksiyon öncesi ve kros klemp sonrası karşılaştırması

Tablo 5. MDA ölçü̈mlerinin gruplara göre dağılımı.

\begin{tabular}{lcccc}
\hline $\begin{array}{l}\text { Malon(il) dialdehit } \\
\text { nmol/mL }\end{array}$ & $\begin{array}{c}\text { Sevofluran } \\
(\mathbf{n = 2 0})\end{array}$ & $\begin{array}{c}\text { Desfluran } \\
(\mathbf{n = 2 0})\end{array}$ & $\begin{array}{c}\text { Kontrol } \\
(\mathbf{n = 2 0})\end{array}$ & $\mathbf{p}$ \\
\hline $\begin{array}{l}\text { Kros klemp sonras1 } \\
\text { (median } \pm \text { SS) }\end{array}$ & $3.60 \pm 1.93^{*}$ & $3.30 \pm 1.65^{* *}$ & $3.15 \pm 0.81^{* * * *}$ & 0.645 \\
$\begin{array}{l}\text { Kros klemp } \\
\text { kaldır1diktan sonra } \\
\text { (median } \pm S S \text { ) }\end{array}$ & $4.65 \pm 1.95^{*}$ & $4.10 \pm 1.99^{* *}$ & $4.35 \pm 0.98^{* * *}$ & 0.599 \\
$\begin{array}{l}\text { Protamin sonras1 } \\
\text { (median } \pm S S)\end{array}$ & $5.10 \pm 1.44 *$ & $5.25 \pm 1.61 * *$ & $5.05 \pm 1.19^{* * * *}$ & 0.900 \\
\hline
\end{tabular}

SS: Standard deviasyon, ${ }^{*}, * *, * * * p<0.05$ (Grup içi karşllaşttrmalarda)

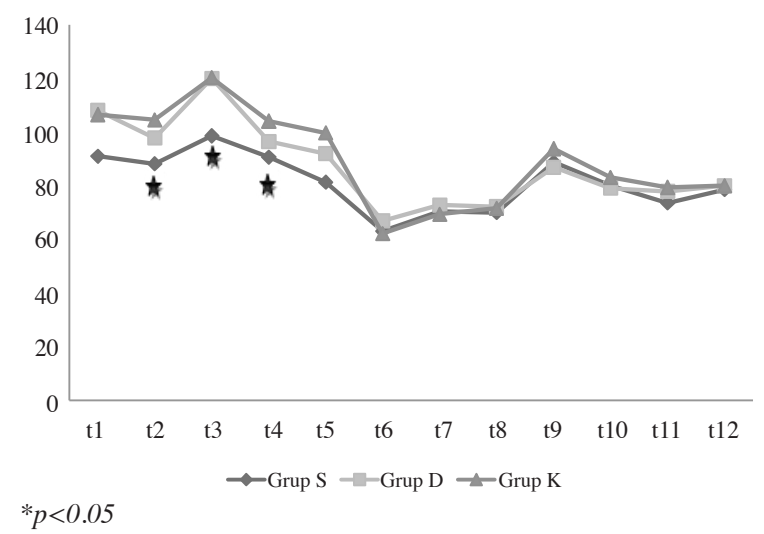

Şekil 1. Ortalama arter basınç değerlerinin gruplara göre dağılımı.

seviyelere inmese de postoperatif 24 . saatteki Troponin I değerindeki azalma postoperatif 2 . saatteki değerlere göre anlamlıydı $(\mathrm{p}<0.05)$. Troponin I ölçümleri açısından gruplar arasında istatistiksel olarak anlamlı fark bulunamadı $(\mathrm{p}>0.05)$.

Sevofluran, desfluran ve kontrol grubundaki olguların her 3'ünde de; indüksiyon öncesi ve kros klemp sonrası CK değerine göre postoperatif 2 . saat ve postoperatif 24. saat CK değerinde meydana gelen artış anlamlıydı. Kreatinin kinaz ölçümleri açısından grup- 
lar arasında istatiksel yönden anlamlı fark bulunama$\mathrm{d}_{1}(\mathrm{p}>0,05)$.

Sevofluran kullanan olguların postoperatif 2. saat CK-MB ölçümleri diğer gruptaki olgulara göre anlamlı olarak düşük bulundu $(\mathrm{p}<0,05)$. CK-MB ölçümleri açısından desfluran ve kontrol grupları arasında anlamlı bir fark saptanmadı $(\mathrm{p}>0,05)$. Sevofluran grubundaki olguların; indüksiyon öncesi CK-MB değerine göre kros klemp sonrası CK-MB değerinde meydana gelen düşme anlamlıydı. Sevofluran, desfluran ve kontrol grubundaki olguların her 3'ünde de, indüksiyon öncesi ve kros klemp sonrası CK-MB değerine göre postoperatif 2. saat CK-MB değerinde meydana gelen artış anlamlıydı.

Malon (il) dialdehit ölçümleri açısından gruplar arasinda anlamlı fark bulunamadı $(\mathrm{p}>0,05)$. Her 3 grupta da kros klemp kaldırıldıktan sonra ve protomin uygulama sonrası değerler kros klemp yerleştirildikten sonraki değere göre artış gösterdi.

\section{TARTIŞMA}

Kardiyak cerrahi sonrası geçici miyokardiyal fonksiyon bozukluğu iyi tanımlanmış bir durumdur. Yeterli revaskülarizasyon yanında efektif miyokardiyal koruma ventrikül fonksiyonlarının sürdürülmesi için gereklidir. Birçok neden postoperatif miyokardiyal fonksiyonu ve miyokardiyal hasarlanmanın derecesini etkilemektedir ${ }^{[8]}$. İskemi ve yeniden kanlanma sırasında hücre içinde ve mitokondriumda artan kalsiyumun, hücre hasarına, kardiyak kontraktilitede azalmaya ve kardiyak fonksiyonlarda bozulmaya neden olduğu bildirilmiştir ${ }^{[9]}$. Volatil anesteziklerin, izole insan ve hayvan kalplerinde yapılan çalışmalar sonucunda postiskemik derlenmeyi hücresel düzeyde iyileştirdiği belirtilmektedir. Desfluran ve sevofluranın morbidite ve mortaliteyi azaltan ve troponin düzeyinde azalma ile belirlenebilen kardiyoprotektif etkileri bulunmaktadır. Yine sevofluranın hücre içi kalsiyumu azaltarak ve yüksek enerjili fosfatları koruyarak miyokardiyal korumayı sağladığı gösterilmiştir ${ }^{[10]}$.

Prospektif, randomize bir çalışmada KPB cerrahisi yapılan yüksek riskli hastalarda devamlı propofol infüzyon tekniği ile inhalasyon anestezikleri (sevofluran ve desfluran) karşılaştırılmıştır. Volatil anestezik uygulanan hastalarda kardiyak performansin daha iyi korunduğu, ayrıca ameliyat sonrası inotropik destek gereksiniminin daha az olduğu bulunmuştur. Volatil anesteziklerin kullanıldı ̆̆ı hastalarda Troponin I düzeyinin daha düşük olduğu görülmüştür ${ }^{[11]}$. Çalışmacılar propofolün miyokard üzerindeki koruyucu etkisinin doz bağımlı olduğunu belirtmişlerdir. Çalışmamızda, sevofluran grubunda indüksiyon öncesi Troponin I değerleri kros klemp sonrasında değişmezken, desfluran ve propofol grubunda yüksek bulundu. Postoperatif 2. ve 24. saatlerdeki Troponin I değerleri başlangıç değerine göre tüm gruplarda artış gösterdi, ancak gruplar arasında bu artış açısından fark saptanmadi.

Sağlıklı bir kişide periferik kanda Troponin I düşük düzeylerdedir, ancak miyokard hasarı durumunda kanda düzeyi artış göstermektedir. Akut miyokard hasarı sonrası 2-4 saat içinde kan düzeyi yükselmekte, 24. saatte zirve yapmakta ve 2-3 hafta süre ile kanda tespit edilebilmektedir ${ }^{[12]}$. Çalışmamızda her 3 grupta da Troponin I değerleri beklenildiği gibi hasar başlamasını takiben tüm gruplarda 2-4. saatte artış göstermiştir.

Ceyhan ve ark. ${ }^{[13]}$ KPB uygulanan hastalara baypas süresi de dâhil olmak üzere sevofluran veya isofluran uygulamışlardır. Çalışma sonucunda sevofluran uygulanan grupta Troponin T düzeylerini kros klemp kaldırıldıktan hemen sonra ve postoperatif 24. saatte daha düşük olarak saptamışlardır. Yine sevofluran grubunda postoperatif 24. saatteki CKMB değerlerinin isofluran grubuna göre daha düşük olduğunu gözlemişlerdir.

Kuyumcu ve ark. ${ }^{[14]}$ açık kalp cerrahisi uygulanan hastalarda total intravenöz anestezi ve inhalasyon anestezisinin iskemi-reperfüzyon hasarı üzerine etkilerini karşılaştırdıkları çalışmalarında, inhalasyon ajanı olarak sevofluran ve desfluran, intravenöz ajan olarak da fentanil ve midazolam kullanmışlar, tüm gruplarda preoperatif değerlerle karşılaştırıldığında postoperatif 2.ve 24. saatlerde serum CK, CK-MB, Troponin I, ALT, AST, IL6, IL8, TNF $\alpha$, değerlerindeki artışlarda gruplar arasında anlamlı bir fark saptamamışlardır. Kariyopulmoner baypas sırasında oluşan iskemi-reperfüzyon hasarını önlemede ve farmakolojik ön koşullandırma oluşturmada inhalasyon ajanları ve total intravenöz anestezi arasında herhangi bir farklılık olmadığ 1 kanısına varmışlardır. 
Kreatinin kinaz kas yıkımını gösteren bir belirteçtir. Miyokardiyal hasardan 4-6 saat sonra yükselir, 24. saatte zirve yapar. Tek başına miyokard hasarını yansıtması açısından spesifik değildir. Çalışmamızda postoperatif 2 . saatte ve 24 . saatte CK değerlerinde artış görülürken, kullanılan anestezik ajanlar arasında farklılık saptanmadı.

Kreatinin kinazın MB formu kalp için nispeten özgüldür, diğer dokularda daha az bulunmaktadır. Akut infarktan 6 saat sonra artış görülmeye başlar, 24. saatte zirve yapar. Çalışma sonuçlarımızda CK MB düzeylerinde postoperatif 2. ve 24. saatlerde artış gözlendi. Ancak bu artış sevofluran grubunda desfluran ve propofole göre daha az olarak saptandı $(\mathrm{p}<0.05)$. Kreatinin kinaz MB tek başına değerlendirildiğinde sevofluranın diğer ajanlara göre miyokard dokusunda daha iyi koruyuculuk yaptığı söylenebilir.

Sayin ve ark. ${ }^{[15]}$ KPB cerrahisinde anestetik ajan olarak propofol ve fentanil sitrat kullanarak iskemireperfüzyon hasarını karşılaştırmışlardır. Kros klemp yerleştirildikten ve kaldırıldıktan sonra ve geç reperfüzyon dönemi olan dekanülasyon periyodunda MDA ölçümü ile lipid peroksidasyonunu değerlendirmişlerdir. Malon (il) dialdehit, lipid peroksidasyon ürünlerinin ayrışması ile ortaya çıkan son ürünlerden biridir ve MDA ölçümü dokulara zarar veren serbest radikalleri değerlendirmenin kolay bir yoludur. $\mathrm{Bu}$ çalışmada, MDA ölçümleri fentanil anestezisi uygulanan grupta artış gösterirken, propofol grubunda değişmemiştir. Sonuç olarak, propofolün lipid peroksidasyonunu kontrol altına aldığı, dolayısıyla iskemi reperfüzyon hasarından korumada KPB sirasinda anestezik ilaç rejiminde kullanılabileceği kararına varılmıştır. Çalışmamızda, bu çalışma ile eşzamanlarda alınan kan örneklerinde MDA ölçümlerinde, inhaler ajanlar ile propofol kullandığımız gruplarımız arasında anlamlı bir fark saptanmadı. Grupların kendi içlerindeki değerlendirilmelerinde de, iskemik dönem, erken ve geç reperfüzyon dönemlerindeki MDA değerlerinde anlamlı olarak artış görüldü. Sonuçta; sevofluran ve desfluran, propofole benzer şekilde lipid peroksidasyonu üzerine etki ediyor şeklinde değerlendirme yapmak olasıdır.

Kullanılan inhaler anestezik ajanların ve propofolün yeterli anestezi düzeyine ulaştığını göstermek açısından BIS monitorizasyonun yapılmamış olması çalışmamızın kısıtlayıcı noktalarından biridir. Ayrıca sevofluran grubunda $\mathrm{OAB}$ nın ölçülen tüm değerlerin diğer gruplara göre düşük seyrettiği görülmektedir. Bunun nedeninin indüksiyon öncesi değerlerinin düşük olması nedeni ile olduğu düşüncesindeyiz. Bu durum, çalışmamızda hemodinamik karşılaştırma sonuçlarımız için kısıtlayıcı bir başka noktadır.

Sonuç olarak, KPB ile kardiyak cerrahi uygulanan hastalarda iskemi ve reperfüzyon hasarını değerlendirmek ve sevofluran ve desfluranın bu hasarın önlenmesinde etkisinin var olup olmadığını araştırmak için propofol ile kontrol grubu oluşturarak yapılan çalışmada kullanılan kardiyak belirteç düzeylerinin arttığı, bu 3 ajanın yeterli düzeyde koruma sağlama$\mathrm{d}_{1} \breve{g ̆}_{1}$ tespit edildi. Sevofluran, desfluran ve propofolün kardiyak koruma açısından birbirlerinden çok büyük üstünlükleri olmadığı görüldü.

\section{KAYNAKLAR}

1. Dhalla NS, Elmoselhi AB, Hata T, Makino N. Status of myocardial antioxidants heart. Cardiovasc Res 1997;33:82-7.

2. Yorulmaz V, Arar C, Turan N, Pamukçu Z. Koroner arter cerrahisinde sevofluran ve yüksek doz fentanil anestezilerinin hemodinami ve postoperatif derlenme üzerine etkilerinin karşılaştırılması. Türk Anest Rea Der Dergisi 2005;33:61-8.

3. Collard CD, Gelman S. Pathophysiology, clinical manifestations and prevention of ischemia-reperfusion injury. Anesthesiology 2001;94:1133-8. http://dx.doi.org/10.1097/00000542-200106000-00030

4. Li C, Jackson RM. Reactive species mechanisms of cellular hypoxia-reoxygenation injury. Am J Physiol Cell Physiol 2002;282:227-41. http://dx.doi.org/10.1152/ajpcell.00112.2001

5. Yağdı T, Özmen $D$, Atay $Y$ ve ark. Perioperatif miyokardiyal hasar tespitinde biyokimyasal markırlar: Troponin'in rolü. GKDC Dergisi 1999;7:175-82.

6. Preckel B, Thamer V, Schlack W. Beneficial effects of sevoflurone and desflurone against myocardial reperfusion injury after cardioplejic arrest. Can J Anesth 1999;46:1076-81. http://dx.doi.org/10.1007/BF03013206

7. Kim KB, Cung HH, Rho JR. Changes in the antioxidative defensive system during open heart operations in humans. Ann Thorac Surg 1994;58:170-5. http://dx.doi.org/10.1016/0003-4975(94)91094-4

8. Tanoka K, Ludwig LM, Krolikowski JG, Alcindor D. Isoflurane produces delayed preconditioning aganist myocardial ischemia and reperfusion injury. Anesthesiology 2004;100:525-31. http://dx.doi.org/10.1097/00000542-200403000-00010

9. Chen Q, Amadou K, Camara S. Sevoflurane preconditioning before moderate hypothermic ischemia protects aganist cytosolic $[\mathrm{Ca}+2]$ loading and myocardial damage in part via mitocondrial K(ATP) channals. 
Anesthesiology 2002;97:912-20.

http://dx.doi.org/10.1097/00000542-200210000-00025

10. Lio H, Wang L, Eaton M. Sevoflurane preconditioning limits intracelluar/mitocondrial $\mathrm{Ca}+2$ in ischemic newborn myocardium. Anesth Analg 2005;100:158493.

11. De Hert SG, Cromheecke S, ten Broecke PW et al. Effects of propofol, desflurane and sevoflurane on recovery of myocardial function after coronary surgery in elderly high-risk patients. Anesthesiology 2003;99:31423.

http://dx.doi.org/10.1097/00000542-200308000-00013

12. Panteghini M, Pagani F, Yeo KT et al. Evaluation of imprecision for cardiac troponin assays at low-range concentrations. Clin Chem 2004;50:327-32. http://dx.doi.org/10.1373/clinchem.2003.026815

13. Ceyhan D, Tanriverdi B, Bilir A. Comparison of the effects of sevoflurane and isoflurane on myocardial protection in coronary bypass surgery. Anadolu Kardiyol Derg 2011;11:257-62.

14. Kuyumcu M, Temur S, Ozsoy M et al. Comparison of the effects of total intravenous anesthesia and inhalation anesthesia on postperfusion injury in cardiac surgery. Gülhane Tip Dergisi 2010;52:18-22.

15. Sayin MM, Ozatamer O, Taşöz R, Kilinc K, Unal N. Propofol attenuates myocardial lipid peroxidation during coronary artery bypass grafting surgery. British Journal of Anaesthesia 2002;89:242-6.

http://dx.doi.org/10.1093/bja/aef173 